\title{
Interaction of steel surface treatment by means of abrasive cloth and adhesive bond strength
}

Müller, Miroslav, Department of Material Science and Manufacturing Technology, Faculty of Engineering, Czech University of Life Science, Kamycka 129, 165 21, Prague, muller@tf.czu.cz

Valášek, Petr, Department of Material Science and Manufacturing Technology, Faculty of Engineering, Czech University of Life Science, Kamycka 129, 165 21, Prague, valasekp@tf.czu.cz

This paper deals with the surface texture influence of by hand grinded steel specimens using abrasive cloth of different grit on the resultant bonded joints strength. This method is often used in repairing and on places where the application of mechanical grinding is not possible. Determination of the optimal surface finish is the necessary step at the bonded joint realization. The evaluation of the roughness influence on the strength characterizations was carried out according to the standard CSN EN 1465 by the use of two two-component epoxy adhesives, namely Bison epoxy metal and Lepox 1200. Bonded specimens were made from the constructional plain-carbon steel S235J0. From carried out tests it followed not only the necessity to perform the specimen surface mechanical finish before bonding, but the optimal grit of the abrasive cloth for the concrete tested material was determined, too. The use of the unfit selected abrasive cloth, or its use with the unfit selected adhesive layer thickness, can cause the expressive loss in tensile strength of the bonded joint.

Keywords: Adhesive bond, adhesive layer thickness, hand grinding, optimal surface finish

\section{References}

[1] ADAMCZAK, S., MAKRELA, W.: Influence of work centre displacements on the estimation of roughness profiles measured with reference methods, Strojnicky Časopis, 2004 vol. 55, no. 1, pp. $33-44$.

[2] BROŽEK, M., MÜLLER, M.: Mechanické vlastnosti spojů lepených sekundovými lepidly. Strojírenská technologie, 2004, vol. 9, no. 1, pp. $9-15$.

[3] BUMBÁLEK, B. et al.: Drsnost povrchu. Praha: SNTL, 1989. 338 p.

[4] COMYN, J.: Surface treatment and analysis for adhesive bonding. International Journal of Adhesion \& Adhesives, 1990, vol. 10, no. 3, pp. $161-165$.

[5] GRANT, L. D. R. et al.: Experimental and numerical analysis of single-lap joints for the automotive industry. International Journal of Adhesion \& Adhesives, 2009, vol. 29, no. 4, pp. $405-413$.

[6] HOLEŠOVSKÝ, F., NOVÁK, M.: Influence of grinding on machine parts with desing notches, Journal - Manufacturing Technology, 2009, vol 9, no: zvláštní číslo, pp. 40 - 46.

[7] HOLEŠOVSKÝ, F. et al.: Studium změn broušené povrchové vrstvy při dynamickém zatěžování, Strojirrenská technologie, 2007, vol. 12, č. zvláštní číslo, pp. 73 - 76.

[8] HOLEŠOVSKÝ, F.: Stanovení zbytkových napětí v povrchu po obrábění. Strojirrenská technologie, 2006, vol. 11, no. 3 , pp. $29-32$.

[9] JENNINGS, C. W.: Surface roughness and bond strength of adhesives. The journal of adhesion, 1972, vol. 4, no. 1, pp. $25-38$.

[10] MAKIELA, W., STEPIEŃ, K.: Method of evaluation of roungness profiles of machine parts using the wavelet analysis. Pomiary Automatyka Kontrola, 2008. no. 5, p. $244-248$.

[11] MESSLER, R. W.: Joining of materials and structures from pragmatic process to enabling technology. Burlington: Elsevier, 2004. $790 \mathrm{p}$.

[12] MITTAL, K. L.: Contact angel, wettability and adhesion. Boston: Brill Academic Publisher, 2003, 532 p.

[13] MÜLLER, M. et al.: Evaluation of factors influencing adhesive bond strength, Research in Agricultural Engineering. 2006, vol. 52, no. 1, pp. $30-37$.

[14] MÜLLER, M. et al.: Hodnocení vlivu integrity lepeného povrchu na změnu pevnostních charakteristik lepeného spoje, Strojirenská technologie, 2007, vol. 12, no. zvláštní ćíslo, pp. 177 - 180.

[15] MÜLLER, M., BROŽEK, M.: Technologie lepení - vliv expirační doby lepidel na pevnost lepených spojů. Strojírenská technologie, 2005, vol. 10, no. 3, pp. $10-16$.

[16] MÜLLER, M., CHOTĚBORSKÝ R., NÁPRSTKOVÁ, N.,: Možnosti hodnocení mechanické úpravy lepeného povrchu. Jemná mechanika a optika, 2006, vol. 51, no. 10, pp. $277-279$. 
[17] PACKHAM, D. E.: Surface energy, surface topography and adhesion. International Journal of Adhesion \& Adhesives, 2003, vol. 23, no. 6, pp. $437-448$.

[18] SHAHID, M., HASHIM, S. A.: Effect of surface roughness on the strength of cleavage joints. International Journal of Adhesion \& Adhesives, 2002, vol. 22, no. 3, pp. $235-244$.

[19] ČSN EN ISO 4287. 1999: Geometrické požadavky na výrobky (GPS) - Struktura povrchu: Profilová metoda - Termíny, definice a parametry struktury povrchu. Praha: Český normalizační institut, 1999. 22 p.

[20] ČSN EN 1465. 1997: Lepidla - Stanovení smykové pevnosti v tahu tuhých adherendů na přeplátovaných tělesech. Praha: Český normalizační institut, 1997. 7 p.

[21] ČSN ISO 10365 1995: Lepidla - Označení hlavních typů porušení lepeného spoje. Praha: Český normalizační institut, $1995.6 \mathrm{p}$.

\section{Acknowledgement}

Supported by Internal grant agency of Faculty of Engineering, Czech University of Life Sciences in Prague, Project No. 31140/1312/313117.

\section{Reviews:}

Prof. Bohumil Bumbálek, MSc., Sc.D. Prof. Iva Nová, MSc., Ph.D. 